\title{
FEMALE PARTICIPATION IN THE LABOUR MARKET OF BOTSWANA: RESULTS FROM THE 2005/06 LABOUR FORCE SURVEY DATA
}

\author{
Happy Siphambe $^{20}$ and Masedi Motswapong ${ }^{21}$
}

\begin{abstract}
This is an empirical paper that looks at the major determinants of labour market participation of females in Botswana using the 2005/06 Labour Force Survey(LFS) data, probit and logit models. Results show that education increases females' chances of participating in the labour market. Marriage impacts negatively on female labour force participation. Moreover, females who live in urban areas are more likely to participate in the labour market than those who live in rural areas and females who are household heads are more likely to participate in the labour market than those who are not. The results also showed that females prefer to work in a private sector than working in the other sectors.

Policy implications are that efforts to address the problem of females' access to the labour market should focus on improving their access to education. The government should continue developing rural areas and create more employment opportunities.
\end{abstract}

Key words: Labour market, gender in the labour market, labour force participation.

\subsection{Introduction}

Labour market outcomes in Botswana, like elsewhere, have a great impact on the well-being of females and most importantly on the survival of their children. In addition, child health is supported by women's empowerment. The rising involvement of women in development and the economy is central to economic growth (World Bank, 1995). However statistics indicate that the labour market in Botswana is male-dominated, despite the fact that females in Botswana are on average more educated than males. Literacy rate for males is 80.3 percent, whereas for females is 81.7 percent (Central Statistics Office, 2003a). In both developed and developing countries discrimination attitudes are reflected in the labour market regulations. Legislation exists in many countries that prevent females from working in certain kinds of occupations. For example in Botswana until 2008, women could not join the army as soldiers. Gender bias exists in the labour markets in the world and Botswana is no exception. The gender differences are associated with unequal access of resources such as time, income and social status. Greater value is placed on productive work outside home while the domestic labour is undervalued and in most cases unpaid. Furthermore, gender divisions in the labour market where females are concentrated in certain occupations such as teaching and nursing are basically viewed as an extension of their domestic roles. Female labour force participation is lower than male participation at all ages (Central Statistics Office, 2003b). However, female labour force participation in the formal sector tends to show an overall increasing trend in recent times and it is spread to almost all ages and particularly high from 20 to 45 years except for ages 12 to 19 years. The reason for this may be because they have attained higher education levels which increases their access to opportunities to work in market activities and raises their market productivity compared with home production.

While the national surveys on the labour force in Botswana have documented its magnitude and contribution in the national economy, little is known about the factors that

\footnotetext{
${ }^{20}$ Associate Professor, Economics Department, University of Botswana

E-mail: Siphambe@ mopipi.ub.bw

${ }^{21}$ Associate Researcher, Botswana Institute of Development Policy Analysis.
} 
determine participation decisions in the labour force, especially given that the rate of participation has been increasing ${ }^{22}$. In 1995/96, the number of persons aged 12 years and above totaled 950,793, with a labour force of 528,108 and making a labour force participation rate of 46.3 percent (Central Statistics Office, 1998). For 2005/06, the number of persons aged 12 years and above was 1,153,228, the labour force being 787,962 and making a labour force participation rate of 56.6 percent. This shows that there has been an increase of about 10 percentage points between the periods. In terms of gender, the labour force participation rate rose from 52.9 percent to 64 percent between 1995/96 and 2005/06 for males which show an increase of 11 percentage points between the periods. As for females, the participation rates increased from 40.5 percent to 50.5 percent between the same periods, showing a 10 percentage points increase. Table 1.1 summarises the changes in labour force participation between 1996 and 2006.

In Botswana like most developing countries, females constitute a significant share of the poor and the unemployed and most females are in the informal sector or work in low paying jobs. This could be due to them having few job opportunities because of occupational segregation, cultural barriers, etc. Despite these observations there is limited empirical work on the factors that influence participation decisions of females and their significance in Botswana. Therefore, this paper presents results of an empirical study on the factors that determine the participation of females in the labour force. The paper also examines the factors that determine the choice of formal sector by females in Botswana relative to other choices.

Table 1.1: Labour force participation and unemployment rates

\begin{tabular}{|l|c|c|c|c|}
\hline Variable & Year & Males & Females & Total \\
\hline Participation rate (\%) & 1996\a & 61.1 & 50.7 & 55.5 \\
\hline & $1998 \backslash \mathrm{b}$ & 61.3 & 42.4 & 51.1 \\
\hline & $2000 \backslash \mathrm{c}$ & 60.1 & 44.2 & 51.7 \\
\hline & $2001 \backslash \mathrm{d}$ & 61.1 & 40.8 & 50.2 \\
\hline & $2001 \backslash \mathrm{e}$ & 56 & 38.8 & 47 \\
\hline & $2003 \backslash \mathrm{f}$ & 60.9 & 47.4 & 53.5 \\
\hline & $2004 \backslash \mathrm{g}$ & 64.9 & 49.8 & 56.7 \\
\hline & $2006 \backslash \mathrm{h}$ & 64 & 50.5 & 56.6 \\
\hline & $1996 \backslash \mathrm{a}$ & 19.4 & 23.9 & 21.5 \\
\hline & $1998 \backslash \mathrm{b}$ & 18.6 & 18.6 & 18.6 \\
\hline & $2000 \backslash \mathrm{c}$ & 14.7 & 17.2 & 15.8 \\
\hline & $2001 \backslash \mathrm{d}$ & 17.6 & 15.8 & 16.8 \\
\hline & $2001 \backslash \mathrm{e}$ & 16.4 & 23.9 & 19.6 \\
\hline & $2003 \backslash \mathrm{f}$ & 21.4 & 26.3 & 23.8 \\
\hline & $2004 \backslash \mathrm{g}$ & 21.7 & 27.8 & 24.6 \\
\hline & $2006 \backslash \mathrm{h}$ & 15.3 & 19.9 & 17.6 \\
\hline
\end{tabular}

Sources;

la 1995-1996 Labour force survey

lb 1998 Demography survey

Ic 2000 Botswana multiple survey

Id 2001 Botswana Aids impact survey

le 2001 Population and housing census
If 2002-2003 HIES

Ig 2004 Botswana Aids impact survey Ih 2005-2006 Labour force survey

\footnotetext{
${ }^{22}$ The labour force (or economically active population) consists of those that during the reference period supply labour to the production of goods and services, this includes persons who were either working or would like to work.

Labour force participation rate measures how many persons are economically active, expressed as percentage of the total
} population (that is $\frac{L F}{P} \times 100$ ) where $L F$ is the labour force and $\mathrm{P}$ is the relevant population aged 12 and above 


\subsection{Selected Literature Review and background of Botswana $\$$ s economic development and growth}

Botswana has had impressive economic growth since gaining independence in 1966 . At independence, the economy depended hugely on beef industry and agriculture. Fortunes were to change after independence due to the discovery and profitable exploitation of diamond mines (Siphambe, 2000). The major strategy was now to exploit the country's mineral wealth and invest proceeds in improving the social and economic condition of the country. Government invested in health and education, which respectively grew at an annual average of 13 and 16 percent from 1976 to 1994 (Tlhobogang, 2006). These investments resulted in substantial improvement in both health status and educational attainment of the labour force. As more people attained education and maintained good health the labour force grew and more employment was created. Available data shows that since independence labour force has been increasing gradually. The formal sector became the main employer, the government being the employer of last resort because of the working conditions that prevailed in the sector, but today the private sector is the largest employer, accounting for 56 percent of the total employment, followed by the central government with 31 percent. The contribution of the private sector has relatively increased in three years, from 55 percent in September 2000 to 56 percent September 2003 (Central Statistics Office, 2003b). According to the 2005/06 LFS, the private sector is currently the main employer with 42 percent of the labour force (Central Statistics Office, 2007) $)^{23}$.

Despite Botswana's success in terms of economic growth and efforts to increase access to education and health, Botswana is faced with shortages of skilled manpower and has a surplus of unskilled labour. To date the country still needs quite a number of expatriates to fill the vacant posts. The Botswana government has, for instance, maintained a relatively laissez-faire approach to labour movements as regards skilled labour and a very strict policy with regard to unskilled labour (Siphambe, 2004). Moreover, the country is challenged by lack of growth in the formal sector, relatively huge wealth disparities and labour markets segmentation reinforcing the social cleavages at large. A majority of the labour force is employed in the "non-wage" employment in subsistence farming in the rural areas and informal activities in the urban areas. According to the 2005/06 LFS, a majority of the workers were employed in the rural areas. The agricultural sector employed the majority of workers; about 56 percent were employed, with lowest average earnings of about P366 per month. Low skills levels, poor systems of industrial relations as well as the impact of HIV/AIDS upon company performance all impact negatively on growth potential.

Female jobs tend to be paid less, less skilled and less secure and lack opportunities for upward mobility, compared to male jobs (Bernard, 1989). The results show that the state and the employer policies tend to favour men when facilitating access to jobs while women are considered part of the supplementary workforce. Buvinic (1996) reporting on occupational segregation between males and females argues that women have narrower occupational choices as compared to males. The increasing trend towards females' participation in the labour market in developing countries has drawn both social and academic attention.

In general, studies reveal a linear relationship between economic development and female labour force participation (Sackey, 2001). It is reported that rapid development is often accompanied by higher female participation, higher levels of schooling for girls and lower fertility rates (Trovato and Vos, 1992). Two general theoretical paradigms are used to explain the way in which the levels of economic development influence patterns of female labour force participation in developing countries. First, modernization theorists hypothesize that a high level of female labour force participation is positively associated with a high level of modernity, which is usually evaluated in terms of economic growth. Fosu (1999) and Sackey (2001) found

\footnotetext{
${ }^{23}$ The distribution of workers by sector differs between the LFS and the other surveys because the LFS excludes the informal sector employees while these are included as part of private sector employment in the other surveys.
} 
that the willingness of married women to participate in the labour force stems from a desire to provide their families with a higher standard of living, underscoring the welfare improvement rationale for female labour force participation. The modernization process is associated with increased demand for labour and with social acceptance of women's employment and greater education, as well as lower fertility rates. From, this viewpoint, increasing female labour force participation means that females benefit from modernization.

Demography is also linked to modernization, since what happens to fertility affects females' labour force participation. Empirical evidence shows that females, especially with older children, and being heads of households will utilise available opportunities for employment. Children are the main reason for them to participate; this is because the survival of their children depends on their access to the labour market. Females are less likely to discriminate in their choice of activities owing to the need to cater for their families (Atieno, 2006). This partly explains why they are found in all types of employment, ranging from permanent employment, temporary employment and self employment. The constraining influence of fertility and the associated demand for childcare time have often been considered as the principal determinants of female labour force participation and as such have featured prominently in the recent empirical and theoretical research on female labour supply. A considerable body of research has been devoted to the study of the impact on fertility of female labour force participation, the hypothesis usually having been that an expansion of female labour force employment would tend to lower fertility rates. Indeed in 2001, Sackey concluded that higher female labour force participation is often accompanied by lower fertility rates. Among development planners in developing countries the possibility that female employment would slow the rate of population growth has encouraged widespread enthusiasm for policies designed to accelerate the growth of the female labour force. Many other academics, as well as international organizations and governments, have accepted that indeed an inverse relationship exist and have accordingly advocated policies to increase female employment.

The second general paradigm is the human capital hypothesis that assumes that females with higher levels of education are more likely to be active in the labour market. The human capital school of thought has depicted education as a process of investment from which returns accrue both to society and to the individuals. Writing on human capital, family planning and their effects on population growth, Psacharopoulos \& Tzannotos (1989), found evidence that fertility and labour force participation are related to such factors as women's education and family planning. Maglad (1998) also emphasize the importance of human capital in increasing female labour force participation. Labour supply studies have found that education affects the probability of female labour market participation positively. Psacharopoulos \& Tzannotos (1989), pp. 198, concluded that "if greater participation of women in the labour force is a desirable goal, education for women may be the prime policy option". With an enhancement of females human capital, they would be equipped to participate in a more productive way in the labour market. Other studies have observed the impact of education on the fertility rates. In such studies women's educational attainment and family planning programmes as a result of being educated are seen to result in reduction in fertility, hence increase the chances of participating in the labour market.

A study done by Sackey (2005) using a probit model concluded that improvements in the educational status of females (in terms of both enrolment and years of schooling) as well as the tendency towards later marriage have been crucial to fertility reduction in Ghana. The study also used the multinomial logistic model to analyse the employment choice. The results showed that agriculture was the dominant industry absorbing the female labour force which was not surprising for Ghana because the economy is dominated by the agricultural economy.

Atieno (2006) analysed the determinants of female labour force participation in the case of the informal sector in Kenya. The author used the multinomial logit model to identify characteristics of individuals participating in different activities in the labour market. The results showed that education, represented by years of schooling, increases females' chances of being employed in the public and private sectors. Household headship and the urban location also had 
significant marginal effects. Land ownership was also found to increase females' chances of being in agriculture, public sector, private and unpaid family work, but not in the informal sector. These results however are surprising; one would expect a female who owns land to have more chances of participating in the informal sector. This is because the informal sector is a small sector in terms of people employed and often it is carried out in the owner's home or plot, so we expect females with land ownership to have more probability of choosing the informal sector because they have one of the main resources. Atieno (2006) however was quick to point out that those counted as employed in the informal sector were actually underemployed. As such, participation in the informal sector is a residual outcome of lack of employment opportunities in the other sectors and not the outcome of changes in the explanatory variables. From Atieno (2006)'s study an important conclusion from the results is that education and household characteristics as well as assets are important in determining women's access to formal sector employment.

This paper adopts the models used by Sackey (2005) and Atieno (2006) to find the determinants of labour force participation in Botswana and also investigate the factors that determine their choice of sectors. This paper adds to the available literature in the world and most important in Botswana where a few systematic studies have been carried out in this field. In addition, the paper also expands on the variables that have been used in the previous studies by adding more variables such as household headship and member of the household working.

\subsection{Model Specifications, Methodology and Data}

The paper uses two models, the probit and the multinomial logistic models ${ }^{24}$. The probit model is used to find out in a more general sense what factors explain female's decision to participate in the labour market. The probit model ignores all occupational differences within sectors, so we used the multinomial logistic model to analyse the occupational differences within the sectors, if females participate in the labour market. The probit model used in this paper has been adopted from Sackey (2005), with some modifications. Sackey (2005) estimated the model of labour force participation using a probit model to find out factors that explain females' decisions to participate in the labour market in Ghana.

The probit model was estimated using the method of maximum likelihood estimation (MLE) method $^{25}$ (Cramer, 1986). The method is computed automatically in STATA.

From the estimated model, the coefficients found serve to provide a sense of direction of the effects of the covariates on participation in the labour market and were used to examine the magnitude of impact. The model was also used to calculate the marginal impact of the right hand side variables on the probability of participation.

In order to look at the employment choices of females we used the multinomial logistic model. The multinomial logistic model is used to identify the individual and household characteristics in employment types. It estimates the probability of individual $i$ participating in sector $j$ given a set of explanatory variables. In the decision to participate in the labour market, any individual female is assumed to attach some level of utility $U$ to any possible alternative choice. She will then choose the activity type or sector that offers the highest utility.

An individual $i$ faced with the decision to choose among $s$ alternatives can be described using the utility function (as derived in Atieno, 2006):

$$
U_{i j}=U_{i j}\left(Y_{i}\right)+\mu_{i j}
$$

where: $U_{i j}$ is the utility that individual $i$ derives from participating in sector $j$.

\footnotetext{
${ }^{24}$ A probit model is a model for binary dependent variables based on the standard normal distribution.

Multinomial logit model is a model for unordered multinomial outcomes in which the regressors vary across individuals

${ }^{25}$ This is a method of estimation that specifies the joint probability of the observed set of data and finds the parameter values that maximise it (i.e. that are most likely).
} 
$Y_{i j}$ is a vector of characteristics of individual $i$.

$\mu_{i j}$ is the disturbance term.

An individual will compare the utility levels between sectors before making a decision to participate. She will choose sector $j$ if and only if the utility derived from it is greater than that for all the other sectors that can be chosen. The dependent variable in the multinomial logit model is grouped into six categories based on the realities of the Botswana labour market; public sector, private sector, agriculture, parastatal sector, Non Governmental Organization(NGO) and unpaid family worker. It can be assumed that individuals take into consideration that their individual household and regional characteristics present both constraints and opportunities to enter into various employment opportunities. The weaknesses of this model however is that it assumes the individual makes a choice, which may not be true given the relatively high unemployment rates faced by females.

The explanatory variables are grouped into the following category:

- $\quad$ individual characteristics (age, education, household headship, marital status,).

- $\quad$ household characteristics (household size)

- $\quad$ regional characteristics (area of residence that is rural or urban).

The sectors of choice are public, private, parastatals, agriculture, NGO and unpaid family worker. Public sector includes central and local government. Parastatals includes the wide range of enterprises owned at least 50 percent by the government, either profit making or non-profit making. Agriculture according to the 2005/06 LFS includes all persons who stated that they were working on their own or family lands or cattle post either in agricultural, livestock or fishing or as paid employees on similar establishments. NGO refers to a legally constituted organisations created by private persons or organisation with no participation or representation of any government. Unpaid family worker refers to individuals who work without pay in an economic enterprise operated by a related person living in the same household. This may involve working in a family business without pay.

This paper uses the data from the 2005/06 LFS. The data was further cleaned to be able to concentrate on the part that is relevant for the study. The definition of labour force followed in the paper is individuals who are either employed or unemployed aged 12 years and above. So those aged between 7 years and 11 years were removed from the sample ${ }^{26}$. The 2005/06 LFS data was collected through a survey by CSO. The sampling framework for the 2005/06 LFS consisted of 4143 enumeration areas derived from the 2001 Population and Housing Census. The sample included 9,760 households in the survey.

\subsection{Empirical Results}

\subsection{General Results}

Table 4.1 provides the descriptive statistics of the variables used in the analyses. The average age of females in the sample is 34 years. In terms of the residence, 24 percent persons live in urban areas, this may explain why they participate less in the labour market because few of them live where there are a vast majority of job opportunities. The rural areas include urban villages. ${ }^{27}$ Thirty eight percent of females are household heads at their homes. This is evident because females still depend largely on men. The table also shows that 17 percent of females are married and 83 percent are either never married, living together, separated, divorced or widowed.

\footnotetext{
${ }^{26}$ The 2005/06 Labour Force Survey asked employment questions to people aged 7 years and above. The inclusion of the 7 year olds was a request from the Department of Labour and Social Security because they wanted to assess and evaluate the extent of child labour (if any) in Botswana.

${ }^{27}$ Urban villages are villages with a 2001 Census population of 5,000 or more and at least 75 percent of its workforce are engaged in non-agricultural economic activities.
} 
Turning to education, 26 of females have no education. Only 24 percent had primary education percent as compared to 42 percent who had secondary school and 6.4 percent had tertiary education. Furthermore, only 1 percent of females had non-formal education.

Thirty percent of females have a household size less than seven and about 70 percent have a household size more than seven. From this data it can be concluded that females in this study have larger household sizes.

Table 4.1: Descriptive Statistics of variables used in the study

\begin{tabular}{|l|c|c|c|}
\hline Variable & Observations & Mean & Std. Dev \\
\hline Age & 10963 & 34.57 & 18.403 \\
\hline Residence & 10963 & 0.235 & 0.4240 \\
\hline H/h Headship & 10963 & 0.381 & 0.4857 \\
\hline Primary edu. & 10963 & 0.236 & 0.4244 \\
\hline Secondary edu. & 10963 & 0.421 & 0.4937 \\
\hline Tertiary edu. & 10963 & 0.064 & 0.2453 \\
\hline Non-formal edu. & 10963 & 0.012 & 0.1095 \\
\hline No education & 10963 & 0.266 & 0.4421 \\
\hline Marital status & 10963 & 0.167 & 0.3726 \\
\hline Household number1 & 10963 & 0.303 & 0.4597 \\
\hline
\end{tabular}

Source: 2005/06 LFS data.

The results in terms of distribution of employed females by sector are shown in table 4.2. From the table we observe that the private sector constituted the majority of the sample. It constituted 57 percent of the total sample, followed by the public sector at 34 percent. The other 9 percent is divided between the parastatal, agriculture and non-governmental organizations. This shows that the private sector is the largest employer in Botswana.

The table also shows that 37 percent of the females participating in the labour force live in urban areas whereas about 63 percent live in rural areas. This again explains why there are fewer females in the labour market than males in Botswana, because the expectation is that people should migrate to urban areas because there are more employment opportunities. Fifty three percent of females that participate in the labour market are household heads. As for marital status, the table shows that only 19 percent of females that participate in the labour market are married. This result shows that being married impacts negatively on the labour market participation. Females who are either widowed, divorced, separated, living together or never married constitute a majority of females about 81 percent participate in the labour market.

Females having household numbers less than seven participate less in the labour market, and those having household numbers more than seven participate more at 25 percent and 75 percent respectively. As for education 70 percent of females participating in the labour market have secondary education, followed by primary and tertiary education at 8 percent and 5 percent respectively. About 7 percent of females have either non-formal education or have never gone to school.

Table 4.2: Descriptive statistics for the data used in the employment sectors

\begin{tabular}{|l|c|c|c|}
\hline Variable & Observations & Mean & Std. Dev. \\
\hline Public sector & 3234 & 0.378 & 0.4730 \\
\hline Private sector & 3234 & 0.572 & 0.4949 \\
\hline Unpaid family worker & 3234 & 0.024 & 0.1525 \\
\hline Parastatal & 3234 & 0.041 & 0.1979 \\
\hline Agriculture & 3234 & 0.020 & 0.1327 \\
\hline Non Governmental Org. & 3234 & 0.008 & 0.0876 \\
\hline Residence & 3234 & 0.374 & 0.4839 \\
\hline Household headship & 3234 & 0.533 & 0.4990 \\
\hline
\end{tabular}




\begin{tabular}{|l|c|c|c|}
\hline Marital status & 3234 & 0.190 & 0.3922 \\
\hline Primary edu. & 3234 & 0.075 & 0.2627 \\
\hline Secondary edu. & 3234 & 0.696 & 0.4600 \\
\hline Tertiary edu. & 3234 & 0.051 & 0.2207 \\
\hline Non-formal edu. & 3234 & 0.007 & 0.0840 \\
\hline No education & 3234 & 0.023 & 0.1505 \\
\hline Age & 3234 & 33.90 & 10.834 \\
\hline Household number & 3234 & 0.249 & 0.4332 \\
\hline
\end{tabular}

Source: 2005/06 LFS data.

\subsection{Results from the probit model}

The probit model takes a linear function of the explanatory variables and applies a nonlinear transformation, in this case using the normal distribution function. The coefficients relate to the underlying linear index (Jones, 2007). The coefficients are therefore interpreted as qualitative effects. So, for example, a negative coefficient means that a female is less likely to be a participant, and a positive coefficient implies that a female is more likely to be a participant in the labour force.

Table 4.3: Results from the probit model

\begin{tabular}{|l|c|c|c|}
\hline Participation & Coefficient & $\mathbf{Z}$ & $\mathbf{P}>\mathbf{~ z ~} \mathbf{~}$ \\
\hline Age & 0.1356 & 21.99 & 0.000 \\
\hline Age squared & -0.0017 & -22.17 & 0.000 \\
\hline Residence & 0.4259 & 12.70 & 0.000 \\
\hline Headship & 0.4349 & 13.25 & 0.000 \\
\hline Marital status & -0.0771 & -1.88 & 0.060 \\
\hline Primary & 0.8876 & 13.87 & 0.000 \\
\hline Secondary & 1.4975 & 24.59 & 0.000 \\
\hline Tertiary & 0.9375 & 11.63 & 0.000 \\
\hline Non Formal & 0.6391 & 4.23 & 0.000 \\
\hline Hhold number & 0.0196 & 0.60 & 0.547 \\
\hline Constant & -4.2176 & -35.07 & 0.000 \\
\hline Log likelihood $=\mathbf{- 4 8 9 3 . 2 4 4 4}$ & & \\
Number of obs $=\mathbf{1 0 9 6 3}=\mathbf{3 4 9 0 . 2 5}$ & & \\
LR chi2 & $\mathbf{0 . 0 0 0 0}$ \\
Prob $>$ chi2 $=\mathbf{0 . 2 6 2 9}$ & & \\
Pseudo R2 $=$ & & \\
\hline
\end{tabular}

Source: 2005/06 LFS data.

The results in table 4.3 show that all the estimates are significantly different from zero with a chi-square of 3490.25 . The results also show the pseudo R-squared of 0.2629 , which measures the goodness of fit of the model and therefore implies that $26 \%$ of the explanatory variables are explained while $74 \%$ are unexplained. The results reflect that our model is good in explaining the determinants of female labour force participation in Botswana, more so that we are using cross sectional data.

From the results, age structure is found to be important in determining the participation of females. Age squared has a negative and significant coefficient and this implies that beyond a certain age females have lower chances of participating in the labour force. As females grow old they participate less in the labour force, their work is likely to be interrupted by periods of household activity. This may also be a cohort effect as older generation of females was participating less in the labour market due to cultural and other issues.

In terms of area of residence females living in urban areas are more likely to participate in the labour market; hence the variable has a positive sign as expected and significant coefficient. 
By implication this means that in urban areas there are more job opportunities; therefore urban area is positively related to female labour market participation in Botswana.

In terms of household headship the results show that the coefficient is positive and significant. The results reflect that a female who is a household head is more likely to participate in the labour market than a female who is not a household head. This is true because as a decision maker in the household, the female has to participate in the labour market.

In terms of the female's education, results show that primary education has a positive and significant coefficient which reflects that a female with a primary education level is more likely to participate in the labour market than a female with no education. Secondary education also shows a positive and significant coefficient reflecting that female having completed secondary education is more likely to participate in the labour market than those with no education. This is true because higher education enhances females to participate more in the labour market. With higher education females have a higher chance of participating in the labour market because they have attained skills and knowledge. Therefore secondary education has a positive effect on the female's entry into the labour market. Tertiary education also has similar results to other education levels. The result means that those females who have certificates, diploma and degrees are more likely to participate in the labour market compared to those who have never attended school. The result implies that females with higher education level are more likely to participate in the labour market. Therefore, the human capital investment in females through education increases their access to opportunities to work in market activities and raises their productivity compared with home production. The results are consistent with the findings of other researchers, who found out that additional schooling enhances a female to participate in the labour market (Atieno 2006, Maglad 1998 and Tsie 2007). Results indicate that even non formal education has positive and significant coefficient reflecting that females who attained non-formal education are more likely to participate in the labour market.

In terms of marital status, results show a negative and significant coefficient (at $10 \%$ significant level). This reflects that married females are less likely to participate in the labour market. Several researches found similar results (Atieno 2006, Tsie 2007 and Wambugu 2002). The reason may be that married females stay at home to carry out household duties. This may also mean that there is no household budget sharing, therefore the wife need not forgo household activities for participation in the labour market. This however means that married females are assisted financially by their husbands. In conclusion we can argue that marriage impact negatively on the labour force participation.

In terms of household number the results show a positive and insignificant coefficient implying that the household number has a positive effect on the female's entry in the labour market but it is not statistically significant.

\subsection{Partial effects for probit model of participation}

To interpret the quantitative implications of the results we need to compute partial effects. The effects in table 4.4 can be given a quantitative interpretation and are measured in probability.

The findings in table 4.4 show that a female with average characteristics, age increases the chance of participating in the labour market by 4 percent. A female who lives in urban areas increases the chance of participating in the labour market by 12 percent. A female who is a household head increases the probability of participating in the labour market compared to a female who is not a household head by 12 percent.

Additional schooling for females raises their chances of participating in the labour market. The probability of a female who has a primary education to participate in the labour market rises by 28 percent, while with secondary education the chances rises by 42 percent and a female with tertiary education increases her chance of participating in the labour market by 32 percent. A female with non-formal education increases the chance of participating in the labour market by 21 percent. A married female reduces the chance of participating in the labour market by 2 percent. 
Table 4.4: Partial effects from the probit model

\begin{tabular}{|c|c|c|c|}
\hline Participation & dF/dx & $\mathbf{Z}$ & $P>|z|$ \\
\hline Age & 0.0359 & 21.99 & 0.000 \\
\hline Residence* & 0.1236 & 12.70 & 0.000 \\
\hline Headship* & 0.1201 & 13.25 & 0.000 \\
\hline Primary edu.* & 0.2774 & 13.87 & 0.000 \\
\hline Secondary edu.* & 0.4221 & 24.59 & 0.000 \\
\hline Tertiary edu.* & 0.3214 & 11.63 & 0.000 \\
\hline Marital status* & -0.020 & -1.88 & 0.060 \\
\hline Household number1* & 0.0051 & 0.60 & 0.547 \\
\hline Non formal edu.* & 0.2112 & 4.23 & 0.000 \\
\hline \multicolumn{4}{|c|}{$\begin{array}{ll}\text { Obs. } P & 0.2938 \\
\end{array}$} \\
\hline & \multicolumn{3}{|c|}{0.1822 (at X-bar) } \\
\hline \multicolumn{4}{|c|}{$\begin{array}{l}\text { Pred. } P \\
\text { Log likelihood }=-4893.2444\end{array}$} \\
\hline \multicolumn{4}{|c|}{ Number of obs $=10963$} \\
\hline$L R \operatorname{chi} 2(10)=349$ & \multicolumn{3}{|c|}{$=3490.25$} \\
\hline Prob > chi 2 & \multicolumn{3}{|c|}{$=0.0000$} \\
\hline Pseudo R2 & \multicolumn{3}{|c|}{$=0.2629$} \\
\hline
\end{tabular}

$\left.{ }^{*}\right) \mathrm{dF} / \mathrm{dx}$ is for discrete change of dummy variable from 0 to 1 $\mathrm{z}$ and $\mathrm{P}>|\mathrm{z}|$ are the test of the underlying coefficient being 0 .

\subsection{Results from the Multinomial Logit model}

Table 4.5 present multinomial logit regression estimates of the choice of employment sectors that females are likely to choose if they participate in the labour market. Wald tests of the hypothesis of the hypothesis that all coefficients except intercepts with each employment sectors are zero, that is, to test if the sectors can be combined. The chi-square statistic for each pair was significant at 1 percent level. Hence the hypothesis may be rejected. A property of the multinomial logit model is that of Independence of Irrelevant Alternatives (IIA). Hausman tests of the null hypothesis that the employment sectors are independent were computed and the data do not reject it. The test statistics are placed at the bottom of Table 4.5. In this paper the private sector is the omitted category, that is, it is served as the base category. The reason why we chose to omit this sector is because we wanted to compare it with other sectors. This is because about 57 percent of females chose this sector, so we wanted to know what made them chose this sector instead of the others. Therefore, the coefficients of other sectors are interpreted as the effect of the associated explanatory variable on the log of odds of the particular employment sector relative to the private sector. Any sector can be omitted to serve as the base category.

The results indicate that female participation in the public sector, NGO and unpaid family worker is likely to increase with age as compared to the private sector. This may be because in the private sector it is believed that people work harder in order to increase the profits of the firm, so by implication these results mean that the more a female gets old, the less she participate in the private sector. Age squared has a negative and significant coefficient for all employment sectors, showing that beyond a certain age females have lower chances of participating in the labour market. A female living in urban areas is less likely to choose the public sector, parastatal, agriculture and unpaid family worker than choose the private sector. This may be because almost all private sector firms that pay higher wages are found in urban areas. This is true for Botswana because most big private sector firms are found in urban areas hence females are more likely to participate in the private sector than any said sector. By implication, the urban area has a vast majority of employment opportunities so females would choose which of the sectors have good working conditions and pay higher wages; therefore they are more likely to choose the private sector because it has all the said conditions.

Household headship is likely to increase participation in the public sector than in private sector. The results show that female household heads are more likely to choose the public sector 
than the private sector because of the working conditions that are there in the public sector. In the public sector there is job security but in the private sector a person may be fired from the job. So as major decision makers in the household females are more likely to choose a sector where their job is secure, hence they are more likely to choose the public sector. Household headship is however insignificant in the other sectors.

The results in table 4.5 show that a female who is married is likely to increase participation in the public sector, parastatal, NGO, agriculture and unpaid family worker than in the private sector. Married females are likely to choose the public sector than the private sector because there is job security in the public sector. This is because they are already committed to their husbands so they want a job that is secure. The other reason is that the government has a policy on transfer which states that married couples should preferably and where possible work in the same locations. That policy is however absent in the private sector, which means in the private sector it may be difficult for them to be transferred to where their husbands are working. So they prefer to work in the public sector because they know that they can be easily transferred to locations where their husbands are working. Furthermore, they may prefer the public sector because of the working conditions that prevail in the sector, for example issues to deal with maternity leaves and compensations. The public sector is known to generally have more liberal conditions of service than the private sector.

A female with primary education is more likely to participate in the public sector than in the private sector as compared to a female with no education. Primary education does not appear to have any effect on participation in either the parastatal, NGO, agriculture and unpaid family worker as compared to the private sector. The results also show that females with secondary education are more likely to participate in the public sector, parastatal and NGO than in the private sector. However, some females with secondary education are less likely to participate in the agriculture and unpaid family worker than in the private sector. Females with tertiary education are less likely to participate in the public sector and agriculture than in the private sector. Tertiary education is however insignificant in participating in other sectors as compared to private sector. Non-formal education is insignificant in explaining the participation decisions in all sectors as compared to the private sector.

Table 4.5: Multinomial Logit estimates of choice of employment sectors by females (Private sector is the base category)

\begin{tabular}{|l|c|c|c|c|c|}
\hline $\begin{array}{l}\text { Explanatory } \\
\text { variables }\end{array}$ & Public sector & Parastatal & NGO & Agriculture & $\begin{array}{c}\text { Unpaid family } \\
\text { worker }\end{array}$ \\
\hline Age & $0.20^{* * *}$ & $-0.11^{* *}$ & $0.27^{* * *}$ & $-0.11^{* *}$ & $0.05^{* *}$ \\
& $\mathbf{( 8 . 0 1 )}$ & $\mathbf{( - 2 . 3 7 )}$ & $\mathbf{( 4 . 1 7 )}$ & $\mathbf{( - 2 . 2 5 )}$ & $\mathbf{( 2 . 1 5 )}$ \\
Age squared & $-0.0015^{* * *}$ & $-0.0015^{* * *}$ & $-0.0023^{* * *}$ & $-0.0014^{* * *}$ & $-0.0014^{* * *}$ \\
& $\mathbf{( - 5 . 0 4 )}$ & $\mathbf{( 2 . 8 4 )}$ & $\mathbf{( - 2 . 8 8 )}$ & $\mathbf{( 2 . 6 7 )}$ & $\mathbf{( 2 . 5 7 )}$ \\
Residence & $-0.77^{* * *}$ & $-1.16^{* * *}$ & $0.74^{* * *}$ & $-1.63^{* * *}$ & -0.30 \\
Headship & $\mathbf{( - 8 . 3 9 )}$ & $\mathbf{( - 3 . 9 1 )}$ & $\mathbf{( 3 . 7 2 )}$ & $\mathbf{( - 3 . 3 9 )}$ & $\mathbf{( - 0 . 7 0 )}$ \\
& $0.46^{* * *}$ & -0.09 & 0.25 & -0.54 & -0.52 \\
Mstatus & $\mathbf{( 5 . 0 3 )}$ & $\mathbf{( - 0 . 3 5 )}$ & $\mathbf{( 1 . 2 1 )}$ & $\mathbf{( - 1 . 7 4 )}$ & $\mathbf{( 1 . 1 5 )}$ \\
& $0.87^{* * *}$ & $1.28^{* * *}$ & $0.97^{* * *}$ & $0.92^{* *}$ & $0.82^{*}$ \\
& $\mathbf{( 7 . 6 2 )}$ & $\mathbf{( 4 . 2 3 )}$ & $\mathbf{( 4 . 3 3 )}$ & $\mathbf{( 2 . 5 0 )}$ & $\mathbf{( 1 . 6 5 )}$ \\
\hline
\end{tabular}




\begin{tabular}{|c|c|c|c|c|c|}
\hline Primary & $\begin{array}{l}0.39 * * \\
(-2.01)\end{array}$ & $\begin{array}{c}0.82 \\
(\mathbf{1 . 5 2})\end{array}$ & $\begin{array}{l}-0.17 \\
(-\mathbf{0 . 3 5})\end{array}$ & $\begin{array}{l}-0.01 \\
(\mathbf{- 0 . 0 3 )}\end{array}$ & $\begin{array}{l}-0.95 \\
(-\mathbf{0 . 7 7})\end{array}$ \\
\hline Secondary & $\begin{array}{c}0.93^{* * *} \\
(\mathbf{7 . 5 4})\end{array}$ & $\begin{array}{l}0.88 * * \\
(\mathbf{2 . 0 8})\end{array}$ & $\begin{array}{c}1.24^{* * *} \\
(\mathbf{4 . 2 1})\end{array}$ & $\begin{array}{c}-1.36^{* * *} \\
(-\mathbf{3 . 5 7})\end{array}$ & $\begin{array}{c}-1.45^{* *} \\
(\mathbf{2 . 1 9})\end{array}$ \\
\hline Tertiary & $\begin{array}{l}-0.49 * * \\
(-2.30)\end{array}$ & $\begin{array}{c}0.40 \\
(\mathbf{0 . 6 1 )}\end{array}$ & $\begin{array}{c}-1.18 \\
(-1.54)\end{array}$ & $\begin{array}{l}1.06 * \\
\text { (2. 68) }\end{array}$ & $\begin{array}{c}-44.7 \\
.\end{array}$ \\
\hline Nonformal & $\begin{array}{l}-0.25 \\
(-\mathbf{0 . 5 1})\end{array}$ & $\begin{array}{c}1.26 \\
(\mathbf{1 . 1 1})\end{array}$ & $\begin{array}{c}0.33 \\
(\mathbf{0 . 3 0 )})\end{array}$ & $\begin{array}{c}0.55 \\
(\mathbf{0 . 5 0 )})\end{array}$ & $\begin{array}{c}-43.14 \\
.\end{array}$ \\
\hline Hhold1 & $\begin{array}{l}-0.01 \\
(\mathbf{0 . 0 6})\end{array}$ & $\begin{array}{l}-0.25 \\
(\mathbf{- 0 . 8 7 )}\end{array}$ & $\begin{array}{c}0.19 \\
(\mathbf{0 . 9 3})\end{array}$ & $\begin{array}{l}-0.95^{* *} \\
(-2.38)\end{array}$ & $\begin{array}{c}0.13 \\
(\mathbf{0 . 2 8})\end{array}$ \\
\hline Constant & $\begin{array}{l}-6.14 * * * \\
(-\mathbf{1 2 . 2 5})\end{array}$ & $\begin{array}{l}-1.89 * \\
(-\mathbf{1 . 8 5})\end{array}$ & $\begin{array}{c}-10.79 * * * \\
\mathbf{( - 8 . 1 8 )}\end{array}$ & $\begin{array}{c}-0.60 \\
(-\mathbf{- 0 . 6 2 )}\end{array}$ & $\begin{array}{c}-7.87 * * * \\
(-3.89)\end{array}$ \\
\hline
\end{tabular}

Notes: $* * *$ significant at $1 \%, * *$ significant at $5 \%, *$ significant at $10 \%$, Figures in parentheses are $\mathrm{z}$ statistics. The sample evidence is for the null hypothesis of IIA. Chi2(38)= -2.69, chi2(38) $=-229.43$, chi2(38) $=0.20$, where P $>$ chi2(38) is 1 , chi2(38) $=5.86$ and chi2(38)= -1.85 with public sector, parastatal, NGO, agriculture and unpaid family worker omitted, respectively.

Source: 2005/06 LFS data.

\subsection{Conclusions and Policy Recommendations}

This paper's main objectives were to investigate the determinants of female labour force participation and also to analyse the employment sectors they prefer if they do participate. The paper uses the 2005/06 LFS data collected by CSO and applied probit and multinomial logit models for the analysis. Our findings are generally consistent with the findings of earlier studies. The results from the probit model show that education, represented by the following categories; primary, secondary, tertiary and non-formal education increases females' chances of participating in the labour market. Higher education increases the probability of participating in the labour market. Urban location also has a positive effect on the participation in the labour market. Females who live in urban areas are more likely to participate in the labour market than those who live in rural areas. A possible explanation for the observation is that in urban areas there are more job opportunities as compared to the rural areas so females have larger pool to choose from hence they are more likely to participate in the urban areas.

Household characteristics are also important in determining females' participation in the labour force. Household headship increases females' chances of participating in the labour market. The results also show that marriage impacts negatively on the female labour force participation.

The results from the multinomial logit model suggest that, education is important in allocating female workers among public sector, parastatal, NGOs, agricultural and unpaid family worker as compared of working in the private sector. In particular education discourages entry into the agricultural sector and unpaid family worker as compared to entry in the private sector. At lower and higher levels education discourages entry into these sectors as compared to entry in the private sector. This may be because education gives access to better opportunities in wage employment that are relatively secure and have stable income. The results show that females with secondary education are more likely to participate in the public sector, parastatal and NGOs as compared to participating in the private sector. This may indicate that these sectors' hiring 
criteria puts emphasis on secondary education much more than the private sector does. However those with tertiary education are more likely to participate in the private sector than any other sector. Higher education enhances participation in the private sector. This may be because this sector is associated with good working conditions and pays higher wages.

Married females are less likely to participate in the private sectors than in any other sector. An important observation is that in this sector has less job security than the other sectors. The results also suggest that females living in urban areas are more likely to choose the private sector as compared to most sectors except for the NGOs. Females who are household heads are more likely to choose the public sector than the private sector. This may be because the public sector is associated with job security.

From a policy perspective, the results imply that providing females with education would be useful investment and a good mechanism for the realization of their empowerment. The quality of human capital in the form of education is important in determining their participation decisions in the labour market. With a better education, they will be better equipped to participate in a more productive way in the labour market. Therefore, the government should continue to close gender gap in education by increasing the girls' enrolment at all levels of education.

The current conditions in the country dictate that females should live in urban areas for them to participate in the labour market and most of them participate in the private sector as compared to other sectors. The policy implication is that Government should equally develop its rural areas. This will give females a large pool of job opportunities to choose from. The government should develop the infrastructure in rural areas as a way to attract foreign direct investment. This will increase job opportunities in rural areas and hence increase chances of participation in the labour market. Participation in the agriculture and unpaid family worker may be more an outcome of the limited employment opportunities. Therefore addressing female participation in the labour market may require addressing the demand side of the labour market, which is creation of employment opportunities.

\section{References}

Atieno, R. 2006. Female participation in the labour market; The case of the informal sector in Kenya. AERC research paper 157. The Regal Press Kenya Ltd. Nairobi, Kenya

Bernard, C.R.,1989. Women, work and achievement. Basingstoke, Macmillan Press Ltd

Buvinic, M.,1996. 'Projects for men in the Third world, explaining their misbehavior'. World Development, Vol 5, No 15. pp 2-9

Central Statistics Office. 1998. Labour Force survey 95/96, Government Printer, Gaborone Central Statistics Office. 2003a. Labour Statistics, Government Printer, Gaborone

Central Statistics Office. 2003b. Botswana Literacy Survey, Government Printer, Gaborone Central Statistics Office. 2007. Labour force survey 2005/06, Government Printer, Gaborone Cramer, J.S. 1986. Econometric applications of Maximum Likelihood Methods. Cambridge University Press. Printed in the United States of America

Cramer, J.S. 1991. An introduction: The Logit Model for Economists. British Library Cataloguing in Publication Data, Great Britain

Fosu, A.K. 1999. 'Cost of living and labour force participation; Married women in urban labour markets'. Journal of Labour Research XX, 20: 219-32.

Heckman, J. 1979. 'Sample Selection Bias as a Specification Error'. Econometrica, Vol 47, No. 1: 153-61.

Jones, A. 2007. Applied Econometrics for Health Economists. A practical guide. Second Edition. Radcliffe Publishing Ltd, United Kingdom.

Maglad, N.A. 1998. Female labour supply in Sudan. AERC Special paper 30, The Regal Press Kenya Ltd, Nairobi, Kenya.

Nam, S. 1991. Determinants of Female labour force participation: A study of Seoul, South Korea, Sociological Forum Vol. 6, No. 4 pp. 641-659. 
Psacharopoulos, G and Tzannatos, Z. 1989. 'Female labour force participation: An international Perspective' The World Bank Research Observer, Vol. 4, No 2. pp.187-201

Sackey, H.A. 2001. Female labour force participation in Ghana; the effects of fertility. Work in progress presented at AERC Biannual Research Workshop. Nairobi, Kenya

Sackey, H. A. 2005. Female labour force participation in Ghana, the effects of education, AERC research paper 150, The Regal Press, Nairobi, Kenya.

Siphambe, H.K. 2000. 'Rates of return to education in Botswana'. Economics of Education Review 19, pp. 291-300.

Siphambe, H.K. 2004. 'Botswana's economy and labour market: Are there any lessons for SADC regional integration?' Development Southern Africa, Vol. 21, No. 2. pp. 353-364.

Tlhobogang, O. 2006. Earnings differentials in the labour market in Botswana: Public vs Private Sector. Unpublished MA dissertation. University of Botswana.

Trovato, F and Vos, R 1992. 'Married Female Labour force participation and Suicide in Canada, 1971 and 1981' Sociological Forum, Vol. 7, No.4, pp. 661-677.

Tsie, G. 2007. The Participation of Rural women in the labour market: A case of Thamaga. Unpublished BA project. University of Botswana.

Wambugu, A. 2002. Employment, Education and Earnings in Kenya. Department of Economics, Goteborg University, Goteborg, Sweden.

World Bank 1995. Towards Gender Equality: the role of the Public Policy. Washington, D.C: The World Bank. 